\title{
Beta-Adrenergic Receptor Kinase 2
}

National Cancer Institute

\section{Source}

National Cancer Institute. Beta-Adrenergic Receptor Kinase 2. NCI Thesaurus. Code C21384.

Beta-adrenergic receptor kinase $2(688 \mathrm{aa}, \sim 80 \mathrm{kDa}$ ) is encoded by the human GRK3 gene. This protein plays a role in the regulation of beta-adrenergic receptor-mediated signaling. 